\title{
Frequency and origin of haplotypes associated with the beta-globin gene cluster in individuals with trait and sickle cell anemia in the Atlantic and Pacific coastal regions of Colombia
}

\author{
Cristian Fong, María Alejandra Lizarralde-Iragorri, Diana Rojas-Gallardo and Guillermo Barreto \\ Laboratorio de Genética Molecular Humana, Departamento de Biología, Universidad del Valle, \\ Cali, Valle del Cauca, Colombia.
}

\begin{abstract}
Sickle cell anemia is a genetic disease with high prevalence in people of African descent. There are five typical haplotypes associated with this disease and the haplotypes associated with the beta-globin gene cluster have been used to establish the origin of African-descendant people in America. In this work, we determined the frequency and the origin of haplotypes associated with hemoglobin $S$ in a sample of individuals with sickle cell anemia (HbSS) and sickle cell hemoglobin trait (HbAS) in coastal regions of Colombia. Blood samples from $71 \mathrm{HbAS}$ and $79 \mathrm{HbSS}$ individuals were obtained. Haplotypes were determined based on the presence of variable restriction sites within the $\beta$-globin gene cluster. On the Pacific coast of Colombia the most frequent haplotype was Benin, while on the Atlantic coast Bantu was marginally higher than Benin. Eight atypical haplotypes were observed on both coasts, being more diverse in the Atlantic than in the Pacific region. These results suggest a differential settlement of the coasts, dependent on where slaves were brought from, either from the Gulf of Guinea or from Angola, where the haplotype distributions are similar. Atypical haplotypes probably originated from point mutations that lost or gained a restriction site and/or by recombination events.
\end{abstract}

Keywords: sickle cell anemia, $\mathrm{HbS}$ haplotypes, betaS globin-gene cluster haplotypes, $\mathrm{HbS}$ in Colombia, Afro-Colombians.

Received: April 30, 2013; Accepted: August 24, 2013.

Sickle cell anemia (SCA) is a hemoglobin disorder characterized by the presence of hemoglobin $\mathrm{S}$ caused by a mutation $(\mathrm{A} \rightarrow \mathrm{T})$ in the sixth codon of the $\beta$-globin gene $(H B B)$, producing a substitution of glutamate for valine, giving rise to an abnormal hemoglobin called hemoglobin $\mathrm{S}(\mathrm{HbS})$. The incidence of SCA in Colombia is higher in coastal regions where more people of African descent live. The frequency of the beta S-globin allele $\left(\beta^{\mathrm{S}}\right)$ in these two regions varies between $5 \%$ and $8 \%$ on the Pacific Coast and from $10 \%$ (Cartagena) to $12 \%$ (Providencia) on the Atlantic Coast (Silva et al., 1998; Bernal et al., 2010).

Five typical haplotypes have been identified in the $\beta$-globin gene cluster, four of which are associated with $\mathrm{HbS}$ in Africa (Benin, Bantu, Senegal and Cameroon) and the other one originates from North India and the Arabian Peninsula (Arab/Hindu) (Pagnier et al., 1984; Lapoumeroulie et al., 1992). These haplotypes have an effect on the severity of the disease. Their variable constituent restric-

Send correspondence to Guillermo Barreto. Laboratorio de Genética Molecular Humana, Departamento de Biología, Universidad del Valle, Calle 13 \# 100-00, Edificio 320, oficina 4040, Cali, Colombia. E-mail: guillermo.barreto @ correounivalle.edu.co. tion sites are therefore becoming candidates for affecting the severity of SCA (Steinberg, 2009). Furthermore, these haplotypes have a well-defined geographic distribution in Africa, making it possible to establish the origin of African-descendant populations in America (Pagnier et al., 1984; Serjeant, 1989).

In a previous study conducted in northwestern Colombia, the haplotypes Bantu and Benin were reported as predominant, suggesting that this population may stem from slaves brought mainly from Angola and São Tomé, in Africa (Cuellar-Ambrosi et al., 2001). Since the frequency and origin of the haplotypes associated with $\mathrm{HbS}$ have not yet been established either on the Atlantic or on the central Pacific coast of Colombia, the purpose of this study was to obtain data to this effect.

Blood samples were collected from individuals who had been classified as positive for sickle cell hemoglobin ( $\mathrm{Hb} \mathrm{S}$ ) using the metabisulfite test at the San Jerónimo hospital in Montería (Department of Cordoba), the Napoleon Franco hospital in Cartagena (Department of Bolivar), both on the Colombian Atlantic Coast, the Hospital Regional de Buenaventura (Buenaventura) and the Hospital Universitario del Valle - HUV (Cali), both on the Colombian Pa- 
cific Coast (Department of Valle del Cauca). Of the samples collected, 52 were from the Pacific and 98 from the Atlantic coast. All the patients in this study were older than 2 years and samples were taken after parents or patients had given written informed consent. This research was approved by the ethics board of Universidad del Valle (Approval act 09-09).

DNA was extracted using the salting out technique (Miller et al., 1988). The genotype at the HbS locus was determined by amplifying the $\beta$-globin 5 ' region, as described by Attila et al. (2004), because this technique allows a precise genotyping of the locus. Amplicons were digested with restriction enzyme DdeI (Fermentas, Vilnius, Lithuania) according to the supplier's instructions. Restriction fragments were visualized by polyacrylamide gel electrophoresis (PAGE) (8\%) with silver staining. Haplotypes were built using restriction enzyme sites in the $\beta$-globin gene cluster $5 \varepsilon$, IVSII $^{\mathrm{G}}$ and IVSII $\gamma^{\mathrm{A}}$ (Varawalla et al., 1992). These sites are haplotype-tagging SNP's (htSNP's) and define the diversity of haplotypes in this region (Liu et al., 2009). In addition to these, the $X m n I$ site was also included because it has an influence on the expression of $\mathrm{HbF}$ (Green $\&$ Barral, 2011). The PCR primers used for this region were: F 5'-CAGGCCTCACTGGAGCTACAGAC-3' and R 5'-ACCTCAGACGTTCCAGAAGCGAGT-3'. These primers were designed using the PRIMER3 software (Untergasser et al., 2012). The PCR cocktail contained $50 \mathrm{ng}$ of genomic DNA in a total volume of $25 \mu \mathrm{L}$ with $0.12 \mu \mathrm{M}$ of each primer, $0.01 \mathrm{mM}$ dNTP's, $1 \mathrm{X}$ TRIS-HC1 buffer ( $\mathrm{pH} 8.4$ ), $50 \mathrm{mM} \mathrm{KC1,} 1 \mathrm{mM} \mathrm{MgCl}_{2}$ and $1 \mathrm{U}$ Taq polymerase (Bioline, London, United Kingdom). The PCR conditions were: initial denaturation at $92{ }^{\circ} \mathrm{C}$ for $5 \mathrm{~min}$, followed by 30 cycles at $93{ }^{\circ} \mathrm{C}$ for $1 \mathrm{~min}$, annealing at $68^{\circ} \mathrm{C}$ for $1 \mathrm{~min}$, extension at $72{ }^{\circ} \mathrm{C}$ for $1.5 \mathrm{~min}$, and a final extension step at $72{ }^{\circ} \mathrm{C}$ for $3 \mathrm{~min}$. DNA fragments were amplified and then digested with the appropriate enzyme to establish the haplotypes. Digestion was performed as described by Varawalla et al. (1992), and the DNA fragments were visualized by electrophoresis in polyacrylamide gels $(8 \%)$ and assembled into haplotypes using the Haploview version 4.2 software (Barrett et al., 2005). In the case of sickle cell trait, the $\mathrm{HbS}$ locus was included to sort out the haplotypes linked to the $\mathrm{HbS}$ mutation from those which were not.

Molecular screening sorted these samples into 79 homozygotes (HbSS) and 71 heterozygotes (HbAS), so 229 chromosomes with the mutation were studied. The most frequently observed haplotypes were Bantu and Benin. However, on the Pacific coast, the frequency of the Benin haplotype was significantly higher than that of Bantu (43\% and $23 \%$, respectively), while on the Atlantic coast, the frequency of Bantu was marginally higher than that of Benin
(33\% and 29\%, respectively). Other "typical" haplotypes had frequencies lower than 6\%. Senegal and Arab/Hindu haplotypes were observed only on the Atlantic coast. This is the first report about the presence of the Arab/Hindu haplotype in Colombia. Worthy of note is the presence, on both coasts, of the Cameroon haplotype (which is limited to a Cameroonian ethnic group, the Eton), with frequencies of $6 \%$ on the Pacific and $4 \%$ on the Atlantic coast (Table 1).

Atypical haplotypes were more frequent on the Atlantic than on the Pacific coast (Table 1), with seven atypical haplotypes described on the former and four on the latter. The haplotype "+---" was observed on both coasts (13\% on the Pacific and $9 \%$ on the Atlantic coast), followed by "-+--", with a frequency of $10 \%$ on the Pacific and $6 \%$ on the Atlantic coast.

Atypical haplotypes could be products of gain or loss of restriction sites in typical haplotypes, and this is probably the cause of the differences observed between atypical and typical haplotypes. This might be the case of the atypical haplotypes "-+--" and "+---", which showed gain of a restriction site compared to the profile of the Benin haplotype. However, more information besides differences in the profile of restriction sites is needed to define the relationship between typical and atypical haplotypes.

The results obtained in this research show that the Benin haplotype is the most frequent on the Pacific coast, a result that is similar to that observed in the Southwest of the United States, in the state of Aragua in Venezuela and in

Table 1 - Distribution of haplotypes associated with hemoglobin $\mathrm{S}$ in Buenaventura, Cali, Montería and Cartagena, Colombia. Frequencies were determined for the number of haplotypes associated with the betaglobin cluster.

\begin{tabular}{lcc}
\hline $\begin{array}{l}\text { Haplotypes } 5 \varepsilon-5 \gamma^{\mathrm{G}}-\mathrm{IVSII}^{\mathrm{G}} \\
\text { IVSII } \gamma^{\mathrm{A}}\end{array}$ & $\begin{array}{c}\text { Absolute frequency } \\
(\%) \text { Atlantic coast }\end{array}$ & $\begin{array}{c}\text { Absolute frequency } \\
(\%) \text { Pacific coast }\end{array}$ \\
\hline Bantu & $52(33)$ & $16(23)$ \\
Benin & $46(29)$ & $30(43)$ \\
Senegal & $10(6)$ & - \\
Arab-Hindu & $1(1)$ & - \\
Cameroon & $6(4)$ & $4(6)$ \\
Atypical -+-+ & $9(6)$ & $7(10)$ \\
Atypical -+--* & $10(6)$ & $9(13)$ \\
Atypical +---* & $15(9)$ & - \\
Atypical +--+\& & $3(2)$ & - \\
Atypical -+++ & $4(3)$ & $1(1)$ \\
Atypical ---+ & - & $2(3)$ \\
Atypical +-+-** & $2(1)$ & - \\
Atypical ++-- & $2(1)$ & \\
\hline
\end{tabular}

*Haplotype derived from the Benin haplotype.

**Haplotype derived from the Bantu haplotype.

\&Haplotype derived from the Cameroon haplotype. 
Canada, where Benin predominates over the other haplotypes (Oner et al., 1992; Moreno et al., 2002). On the Atlantic coast of Colombia, the Benin and Bantu haplotypes have very similar frequencies, a situation similar to that reported by Lyra et al. (2005) for Salvador, Bahia, Brazil. The predominance of those haplotypes on the Atlantic coast of Colombia may indicate migration from the Gulf of Guinea and South West Africa, resulting in a differential distribution of haplotypes on both coasts, due to the different sites where the slaves were brought from.

Since 1640, the Colombian Pacific coast had received a massive influx of slaves from the West coast of Africa (Benin, Ivory Coast, Guinea-Bissau, Senegal, Sierra Leone, and Mali), mainly to work in the local mines (Postma, 1975). As the Benin haplotype is predominant in these regions of Africa (Pagnier et al., 1984), this probably explains the high frequency of the Benin haplotype on the Colombian Pacific coast. On the other hand, the Atlantic coast received, ever since the beginning of the slave trade, individuals from Sene-Gambia (where the Benin haplotype has a high frequency) as well as from Angola, where the Bantu haplotype is the most frequent. These slaves were taken to mining areas within Colombia (Navarrete, 2005). It should be noted that the frequency of the Benin haplotype on the Pacific coast (43\%) differs from that reported by Cuellar-Ambrosi et al. (2001) for this haplotype (34.8\%). Apparently, the Central and Northern Pacific coasts underwent different periods of settlement, with settlers of different origins.

The atypical haplotypes observed in this population may have been generated by recombination between a $\beta^{S}$ and an A chromosome, through a hot-spot recombination in the $\delta$-globin 5 ' region. Another mechanism could be the loss or gain of a restriction site through point mutations (Zago et al., 2000). The high number of atypical haplotypes on the Atlantic coast could be due to the arising of an isolated population called "Palenque". Such settlements are prone to high endogamy, which increases the frequency of "rare" haplotypes.

The high frequency of Benin and Bantu haplotypes could result in a high incidence of severe cases of SCA in Colombia. It is therefore important to establish the clinical impact of atypical haplotypes on this disease.

\section{Acknowledgments}

The authors thank the people living in the Pacific and Atlantic coastal regions for their willingness to participate in this study. They also thank hospitals San Jeronimo (Monteria), Napoleon Franco (Cartagena), and Hospital Regional de Buenaventura y HUV (Cali), Colombia. Colciencias is acknowledged for financial support to this re- search (contract grant number: 511-2009, code: 1106493-26235) and for a Doctoral Fellowship to CF.

\section{References}

Attila G, Yalin S, Tuli A, Yalin E and Kiymet A (2004) Prenatal diagnosis of sickle cell anemia in twin pregnancies and identification by VNTRs. Clin Chim Acta 350:137-142.

Barrett JC, Fry B, Maller J and Daly MJ (2005) Haploview: Analysis and visualization of LD and haplotype maps. Bioinformatics 21:263-265.

Bernal M, Collazos A, Bonilla RD and Tascón EA (2010) Determination of the prevalence of hemoglobin S, C, D, and G in neonates from Buenaventura, Colombia. Colomb Med 41:141-147.

Cuellar-Ambrosi F, Mondragón MC, Figueroa M, Pichu C, Galacteros F and Ruiz-Linares A (2000) Sickle cell anemia and $\beta$-globin gene cluster haplotype in Colombia. Hemoglobin 24:221-224.

Green NS and Barral S (2011) Genetic modifiers of HbF and response to hydroxyurea in sickle cell disease. Pediat Blood Cancer 56:177-181.

Lapoumeroulie C, Dunda O, Ducrocq R, Trabuchet G, MonyLobé M, Bodo JM, Carnevale P, Labie D, Elion J and Krishnamoorthy R (1992) A novel sickle cell mutation of yet another origin in Africa: The Cameroon type. Hum Genet 89:333-337.

Liu L, Muralidhar S, Singh M, Sylvan C, Kalra IS, Quinn CT, Onyekwere OC and Pace BS (2009) High-density SNP genotyping to define beta-globin locus haplotypes. Blood Cell Mol Dis 42:16-24.

Lyra I, Gonçalves M, Pellegrinei Braga J, Carvalho M, Gesteira M, Olalla Saad S, Figuereido M and Ferreira Costa F (2005) Clinical, hematological and molecular characterization of sickle cell anemia pediatric patients from two different cities in Brazil. Cad Saúde Pública 21:1287-1290.

Miller SA, Dykes DD and Polesky HF (1988) A simple salting out procedure for extracting DNA from human nucleated cells. Nucleic Acids Res 16:1215.

Moreno N, Martinez JA, Blanco Z, Osorio L and Hackshaw P (2002) Beta-globin gene cluster haplotypes in Venezuelan sickle cell patients from the State of Aragua. Genet Mol Biol 25:21-24.

Navarrete MC (2005) Génesis y Desarrollo de la Esclavitud en Colombia: Siglo XVI y XVII. Programa Editorial Universidad del Valle, Cali, 377 pp.

Öner C, Dimovski A, Olivieri N, Schiliro G, Codrington J, Fattoum S, Adekle A, Öner R, Yüregir G, Altay C, et al. (1992) $\beta^{\text {s }}$ Haplotypes in various world populations. Hum Genet 89:99-104.

Pagnier J, Mears JG, Dunda-Belkhodja O, Schaefer-Rego KM, Beldjord C, Nagel R and Labie D (1984) Evidence for the multicentric origin of the sickle cell hemoglobin gene in Africa. Proc Natl Acad Sci USA 81:1711-1773.

Postma J (1975) The origin of African Slaves: The Dutch activities on the Guinea Coast, 1675-1795. In: Engerman SL and Genovese ED (eds) Race and Slavery in the Eastern Hemisphere: Quantitative Studies. Princeton University Press, Princeton, pp 33-49.

Serjeant GR (1989) Geography and the clinical picture of sickle cell disease. An overview. Ann N Y Acad Sci 565:109-19. 
Silva J, Malambo D, Silva DF, Fals E, Fals O and Rey J (1998) Tamizaje de hemoglobinopatías en una muestra de la población infantil de Cartagena. Pediatria 33:86-89.

Steinberg MH (2009) Genetic etiologies for phenotypic diversity in sickle cell anemia. Sci World J 18:46-67.

Untergasser A, Cutcutache I, Koressaar T, Ye J, Faircloth BC, Remm M and Rozen SG (2012) Primer3 - New capabilities and interfaces. Nucleic Acids Res 40:e115.

Varawalla N, Fitches A and Old J (1992) Analysis of $\beta$-globin gene haplotypes in Asian Indians: Origin and spread of $\beta$-thalassaemia on the Indian subcontinent. Hum Genet 90:443-449.

Zago MA, Silva WA, Dalle B, Gualandro S, Hutz MH, Lapoumeroulie C, Tavella AG, Araujo JE, Krieger JE, Elion J, et al. (2000) Atypical $\beta^{S}$ haplotypes are generated by diverse genetic mechanisms. Am J Hematol 63:79-84.

Associate Editor: Mara H. Hutz

License information: This is an open-access article distributed under the terms of the Creative Commons Attribution License, which permits unrestricted use, distribution, and reproduction in any medium, provided the original work is properly cited. 